\title{
As imagens da matéria em Siciliana (1954-1955) de Murilo Mendes
}

The images of the substance in Siciliana (1954-1955) of Murilo Mendes

Denise Scolari Vieira

Unioeste deniseantonia@hotmail.com

RESUMO: Murilo Mendes, na obra Siciliana (1954-1955), constrói sua expressividade estética entre a atitude filosófica e a pesquisa formal. Os indícios dessa composição se manifestaram no terreno das múltiplas territorialidades através do persistente trabalho que o autor empreendeu ao percorrer direções em duplo movimento, para decifrar ao Outro e restabelecerse a si próprio. Para a formulação da análise serão tomados os pressupostos da Teoria da Imaginação da Matéria, de Gaston Bachelard, na hipótese que reconhece a filiação moderna de Murilo Mendes e para explicitar as imagens da matéria que são recorrentes nos poemas.

Palavras-chave: Poesia. Murilo Mendes. Teoria da Imaginação.

ABSTRACT: Murilo Mendes, in the work Siciliana (1954-1955), constructs his aesthetic way of expressing himself between the philosophical attitude and the formal research. The indications of this composition were shown in the field of the multiple territorialities through the persistent work that the author undertook to take directions in a double movement, to decipher the Other and re-establish himself. The analysis creation it's going to be based on Theory of the Substance's Imagination, written by Gaston Bachelard, in the hypothesis that recognizes the modern filiation of Murilo Mendes; and also to show the images of the substance that are recurrent in poems.

Keywords: Poetry. Murilo Mendes. Theory of the Substance's Imagination. 


\section{Primeiras palavras}

O sujeito poético muriliano nada mais é que representação alegórica do agenciamento pelo indivíduo de um lugar concreto e específico de cruzamento das tradições que o antecedem e ultrapassam (MORICONI, 1997, p. 70).

Tomar a ideia de "eu sou o outro" abre espaço para a tendência da poética moderna. Ao adotá-la, Murilo Mendes nega rotulações, mas por outro lado é regido por esse princípio anárquico que ele ajudou a consolidar. Siciliana é o testemunho dessa proposição porque a forma de construção da obra, a partir de acontecimentos históricos no tempo objetivo, instaura as relações do passado com o presente, entretanto, não significa mera sucessão, de constatação objetiva; ao contrário, o registro escrito das recordações exclama a revisitação cultural que é resgate, mas também refiguração de si mesmo, salientando fortemente uma fisionomia reaberta a novas evocações. Os desdobramentos da invenção especulativa de Murilo Mendes preservam

A consciência da linguagem ('estamos vestidos de alfabeto') e a consciencia da inoperância da linguagem ('o amor é minha biografia / texto de argila e fogo'). A letratexto, a plasticidade da palavra, a autópsia do significante estarão sempre em conflito com as visões e alegorias do poema muriliano. E não há vitória nem derrota. A articulação poética ai é a de um rapsodo ambulante, e sua atlética e decidida vontade de 'virar a vida pelo avesso', assumindo a sua contundência, sua loucura, sua essência. (ARAÚJO, 1972, p. 46).

Os elementos semânticos cambiantes, conjunto descentrado, de caráter contrastivo, fragmentário, articulando discursos diversos, 
figuram em Murilo Mendes a recorrência de uma prodigiosa subjetividade que fala do convulsivo sem sentido da existência, através da palavra errática. Ressalve-se, porém, que também pelas apropriações de plurais geografias, pelo fulgurante teor humorístico, pelo verso livre, pela dinamicidade gráfica, pela exuberância imagética, pelo movimento das formas de sua lírica poliédrica, soube tornar evidente a intensidade entre fazer poético e projeto estético, submetidos, propositadamente à responsabilidade do poeta de construir um novo mundo: "através dos séculos o poeta é encarregado, não só de revelar aos outros, mas de viver praticamente no seu espírito e no seu sangue a vocação transcendente do homem" (MENDES, 1997, p. 871).

$\mathrm{Na}$ obra de Murilo Mendes verificam-se os movimentos de transformação incorporados à poesia brasileira ao longo de um período notadamente expressivo, inventivo, irregular, diverso, legítimo sistema de representação simbólica do Brasil e do mundo, fundamental pela implicação reflexiva e de reinterpretação cultural que é capaz de explicitar. No início, irá construir a sua obra poética aliando à realidade do Brasil dos anos 1930, da conjuntura experimental modernista, a peculiaridade de autor não afeito a movimentos, o que o conduziu ao espírito de liberdade e universalidade. Sua obra surge e consolida-se com uma questão crucial: ser a confluência entre a tradição e o novo, longo caminho percorrido ao lado da co-presença, da exaltação da polifonia.

$\mathrm{Na}$ tipologia da obra muriliana é possível constatar as linhas centrais do desenvolvimento cultural do séc. XX, uma vez que exibe clara atração pela modernização das linguagens. As correntes artísticas advindas do cenário anglo-saxão, francês, ibérico, italiano, etc. enriquecem o espectro da construção identitária do autor e 
assinalam um ponto de partida para a criação de uma estética própria. A hipótese apresentada por inúmeros investigadores da obra de Murilo Mendes acentua o interesse especial do escritor pela vitalidade de todas as linguagens sem, contudo, querer referir-se a si próprio como determinado por alguma dimensão especial e única.

A tendência da poesia de Murilo Mendes refere-se à elaboração plural, afirma seus antecedentes barrocos, não somente pelo impulso de transformação permanente, mas também pela tensão dos opostos. No jogo de reconhecimentos e afastamentos, Murilo Mendes inaugura sua escrita nos anos 20 com ousadia e gesto modernista, realiza seu esquema vital de uma realidade inventada para ser a circunstância da utopia, opções políticas e práticas linguísticas que produziram a (re)semantização da identidade, no cenário de acontecimentos sociais de contexto capitalista periférico. Industrialização acelerada ou emergente, lutas políticas de reforma universitária, propostas anti-imperialistas, reivindicações étnicas e sociais, revoluções em marcha, enfrentamento às ditaduras constituem fenômenos que têm lugar na América Latina nas primeiras décadas do séc. XX e que, em relação à Europa e entre si, manifestam-se imersos na complexidade (PIZARRO, 1995, p. 19-28).

$\mathrm{Na}$ América Latina os símbolos da modernidade surgem no cenário da urbanização crescente e desigual: de um lado, a industrialização; de outro, a persistência da estrutura agrária. A partir dessa realidade, é forjada a memória como dado básico de identidade coletiva e fruto dessa urbanização problemática também surge a abertura para a expressão de novos setores sociais, espacialidades que passam a ser a força das formações culturais com perfil étnico, para, acima de tudo, focalizar a expressão própria, longe dos estereótipos e da folclorização. Portanto, as dinâmicas do distinto desenvolvimento materializaram a tensão entre tendências 
modernizantes que unicamente possuíam novas formas para falar dos mesmos conteúdos e aquelas que, a partir dessas novas estéticas, formularam novos significados.

Ao longo do séc. XX, os escritores latino-americanos parecem ter vivido a constante tensão entre a modernização e o resgate da memória, estando, sempre, no espaço de constituição da cultura periférica, colonial e pós-colonial, com claro interesse pela revitalização de sua cultura, acentuando a continuidade de seu processo identitário ou, ao contrário, exaltando a cultura hegemônica e negando os componentes culturais sincréticos próprios.

Murilo Mendes reuniu em sua obra a máxima relevância dos contatos e intercâmbios, modernizou seu discurso como elemento de discussão, esteve atento às variações importantes do Brasil, da América Latina e do mundo, mudou a palavra e, através desta, a vida: "meu espírito jamais poderia aderir a uma verdade provisória ou parcial, a um sistema relativo dependente das flutuações de uma época" (MENDES, 1997, p. 890).

Caracterizada pela mutabilidade permanente e resistente aos enquadramentos, os poetas do séc. XX têm em comum a multiplicidade de direções. O sistema simbólico dessa escrita advém da consciência de ruptura. Houve o exílio voluntário, mas também a volta às fontes, como propôs Octavio Paz, ao falar de determinados poetas; mas em vários deles a viagem esteve presente e propiciou o contato com outros sistemas simbólicos. No caso de Murilo Mendes, estabeleceu uma organização capaz de reelaborar a consciência da identidade e promover experimentações, entre elas a escrita memorialística esboçada através do contraponto de planos, focos e enquadramentos típicos da expressão plástica e da montagem 
cinematográfica, formas que emergem para falar da infância, da existência, do agora, para refigurar o tempo cultural, episódios da biografia do autor mesclados com conhecimentos da tradição e da inovação trazidos pela experiência e pelo convívio com poetas, pintores, cineastas, músicos, aos quais Murilo Mendes dedicou muitas páginas.

A fim de poder formular sua expressão artística, foi coerente a uma herança cultural ampla. O escritor assumiu a influência da forma livre de Rimbaud. Já Mallarmé, conhecido por categorizar a poesia do intelecto e da forma rigorosa, ganha em Murilo Mendes um adensamento menos rígido. Da essência do modernismo brasileiro de 22, o autor irá considerar o princípio da universalidade e da liberdade; do modernismo anglo-americano, absorve a inesgotável tradição da ruptura; a geração de 27 espanhola também ocupa explícita manifestação e respeito porque traz clara alusão a uma aliança entre a tradição e o novo; no surrealismo aprende a atrevida aventura de descrever a poesia em tempos e espaços distintos, concretizando a possibilidade de apreender a totalidade humana, assim, transforma o mundo pela imaginação, tem acesso às colagens no espaço de coexistências, apartado dos limites temporais; na experimentação concretista imprime à forma o exercício de destruição-construção para transformar os conceitos instituídos (FRIAS, 2002, p. 25).

Para Joana Matos Frias, além dessa apropriação transtextual de obras e autores de vários espaços e tempos, nomeada de "heterogênese" pelo aspecto polidimensional de sua obra poética, Murilo Mendes também possui uma evidência que foi qualificada pela "homogênese", isto é, Frias determina o formante que regula a 
lógica interna da poética muriliana num sistema filosófico descrito como Essencialismo:

Em rigor, a homogênese essencialista sobredetermina quatro princípios matriciais que constituem as raizes da estrutura poetológica de Murilo Mendes: i) a universalidade da arte, e, concretamente, da poesia; ii) a definição do artista-poeta como estabelecedor de relações, $e$, portanto, centro de convergência; iii) o entendimento da obra ou do texto como lugar de conciliação de contrários; iv) a necessidade de abstração do espaço e do tempo. (FRIAS, 2002, p. 68).

Por isso justifica-se a percepção do escritor quando destaca imagens no método poético, com a força do espírito artístico moderno; ao escrever Siciliana (1954-1955), Murilo Mendes registra a vivencia no exílio respondendo já à nova sistematização da escrita, por um lado praticando o deslocamento para o conceito mais classicizante, cultivado entre muitos modernistas como mais uma experimentação, por outro lado não se esgotam os múltiplos itinerários vivenciados pelo autor. Agora, os diagramas mentais edificados, a partir da aplicação dos fundadores, podiam sofrer correções e operar transformações, pois o poeta entorpecido pela extensa geografia e no extenso tempo metaforizado no cenário da Sicília inicia uma nova maneira de viajar.

A partir de 1957, Murilo Mendes fixa residência na Itália, e Siciliana representa simbolicamente uma renovação no percurso de fruição e reflexão estéticas. Lugares visitados configuram a física das cidades, expõem o olhar do colecionador, autorizam proposições interpretativas que pertencem ao reino do imaginário afetivoindividual, atravessam a tensão codificada e própria do sistema

Revista Texto Poético | ISSN: 1808-5385 | Vol. 18 (10 sem-2015) - p. 114 
cultural do escritor de periferia em seu deslocamento para o centro. Entretanto, a pesquisadora Maria Luiza Scher Pereira tem motivos particularmente distintos de esboçar essa questão:

No caso de Murilo Mendes, a atração pela Europa, tão imperativa que ele para lá se muda, estabelece uma relação que parece, diferentemente, formular-se por mediações de outras ordens, como a afetivo-pessoal, pelo casamento com Maria da Saudade Cortesão, e pelo convívio familiar com o conceituado historiador e crítico de cultura, Jaime Cortesão, tornado sogro e amigo. Também, pela mediação de uma ordem afetivo-intelectual, construída, por exemplo, pela amizade de toda vida com Vieira da Silva e Arpad Szenes, que, como Murilo, desterritorializam-se, e desterritorializaram, a seu modo, os conceitos de pátria e nação; e, mais amplamente, pela convivência amigável e permanente com artistas e escritores europeus, sobretudo italianos, mas também com brasileiros em estadia na Europa, como largamente informam seus biógrafos, como a já mencionada Luciana Stegagno Picchio. (PEREIRA, 2002, p. 16).

Em conformidade com os impulsos circunstanciais, o plano criativo submete-se a novas arquiteturas, aprende a severidade da Sicília, ausculta suas linhas de força, abstrai os limites de sua história. Portanto, a expressiva materialização da escrita muriliana traz inúmeras referências que são fruto dos deslocamentos pelas paisagens nas quais o autor rememorou temporalidades e apresentou uma enigmática vinculação afetiva, tendência dual para falar do significado das influências em sua criação artística; investigar a linguagem desse jogo simbólico traz a necessidade de compreensão dessas vivências e também possibilita estabelecer os vínculos com a historiografia literária brasileira recente às quais o autor esteve vinculado.

Revista Texto Poético | ISSN: 1808-5385 | Vol. 18 (10 sem-2015) - p. 115 


\section{Deixar o Brasil e encontrar a Itália}

Murilo Mendes casa-se em 1947 com Maria da Saudade Cortesão e, em 1952, faz sua primeira excursão à Europa, visita a Espanha como turista, mas volta a este país em 1953 como professor visitante da Universidade de Madri.

Entre 1953 e 1955 viaja pela Bélgica e pela Holanda como conferencista. Volta ao Brasil em 1956, visita Minas Gerais, rememorando a obra de 1954, Contemplação em Ouro Preto (19491950).

Em 1957 retorna à Europa e se estabelece com Maria da Saudade em Roma. Convidado pelo Departamento Cultural do Itamaraty, Murilo Mendes passa a atuar como Professor de Estudos Brasileiros, na Universidade La Sapienza.

O testemunho de descoberta da paisagem italiana se materializa na obra Siciliana (1954-1955). O reconhecimento viria pela aproximação de amizades significativas. Giuseppe Ungaretti traduziu alguns textos para o italiano e Dámaso Alonso para o espanhol.

Sua invenção criativa é novamente estimulada, pela confluência fascinante desse espectro de alteridades que formam a trama poliédrica da vivência europeia.

Luciana Stegagno Picchio, uma das maiores intérpretes da obra de Murilo Mendes, explica:

Como a maioria dos brasileiros cultos da sua geração, Murilo Mendes tinha um notável conhecimento do mundo francófono. Quando, pela primeira vez, nos anos 40 transpôs o Atlântico e chegou a Paris, o seu encontro com Revista Texto Poético | ISSN: 1808-5385 | Vol. 18 (10 sem-2015) - p. 116 
a cultura de língua francesa foi um reencontro. Os poetas $e$ os intelectuais em geral que ele encontrava (desde Breton, René Chair ou Maurice Blanchard) já os conhecia de leitura e de carta. Ou mesmo (como Bernanos, Le Corbusier, Camus, Henri Michaux, ou Michel de Ghelderode) de uma frequentação brasileira anterior à sua viagem. (1999, p. 2).

A crítica literária esclarece que o mesmo não se pode dizer a respeito da cultura italiana:

Murilo quando chegou aqui conhecia Dante e São Francisco de Assis, Leopardi e Campana, Ungaretti, Montale e Quasímodo. Mas não falava italiano e só depois de muito tempo, com a invenção diária de textos para os catálogos de pintores e artistas plásticos amigos, ele adquirirá aquela posse da nossa língua que o autorizará, em 1968 a tentar os poemas italianos de Ipotesi, mantidos secretos, como se sabe, até a morte e publicados póstumos só em 1977. (PICCHIO, 1999, p. 2)

Mas o "substrato imagístico europeu”, nas palavras de Cecília de Macedo Garcez, devido à europeização de Juiz de Fora, centro cultural de Minas até a década de 30, haveria de afirmar-se para Murilo Mendes; contudo, ele romperia os limites, "colecionando espaços". Cecília Garcez explica:

Dessa forma, a ligação com a civilização europeia (em particular, a francesa), imperativo na vida social da Juiz de Fora do início do século, no caso do menino Murilo Mendes, apresenta-se na obra, como mais do que um modismo, ou uma imposição social, ou uma aceitação passiva de modelos de prestígio, antes seria parte de uma orientação psicológica e subjetiva em que atua ainda a admiração intensa pelo legado cultural do Velho Mundo. (GARCEZ, 2000, p. 51). 
Murilo soube aproximar-se das fontes e motivos da vida moderna, mas também foi capaz de adicionar o novo, fundiu planos perceptivos para esboçar seu juízo sobre o mundo. Esse processo de interação simbólica entre o Eu/Outro, iniciado no espaço nacional, acolhe em Murilo Mendes a possibilidade de um hibridismo cultural, entretanto, a lógica identidade/diferença o acompanha frequentemente e produz no poeta o estranhamento do "entre-lugar", intervenção típica da modernidade, gerador de uma nota melancólica, muitas vezes pronunciada, outras oculta, porque o rito de iniciação extraterritorial e intercultural é doloroso: "os recessos do espaço doméstico tornam-se os lugares das invasões mais intricadas da história. Nesse deslocamento, as fronteiras entre casa e mundo se confundem e, estranhamente, o privado e o público tornam-se parte um do outro, forçando sobre nós uma visão que é tão dividida quanto desnorteadora" (BHABHA, 1998, p. 30).

Murilo Mendes confirmaria a atitude libertária de romper a banalização da vida cotidiana, levaria a cultura da nação "inconscientemente" e, pela linguagem literária, haveria de permitir que a memória falasse. Entretanto, a complexidade dessa situação, tensionada por esse sujeito do "entre-lugar", que constrói a identidade nos domínios do deslocamento da diferença, circunscreve Murilo Mendes ao corpo coletivo dos autores latino-americanos que se afiliaram à opção do exílio voluntário. Essa atitude acaba por revestir-se de uma significação simbólica com o passado, portadora de um sentimento de descontinuidade porque mergulha no inacessível: 
Memória-espelho, dir-se-ia, se os espelhos não refletissem a própria imagem, quando, ao contrário, é a diferença que procuramos ai descobrir, e, no espetáculo dessa diferença, o brilhar repentino de uma identidade impossivel de ser encontrada. Não mais uma gênese, mas o deciframento do que somos à luz do que não somos mais. (NORA, 1993, p. 20).

$\mathrm{Na}$ emergência desses interstícios, Murilo Mendes chega à Itália no momento em que o sentimento de derrota no cenário do pós-guerra era predominante. As certezas haviam sido eliminadas, e a geração de 45 trazia um espírito civilizatório e redentor nas letras, os intelectuais conclamavam a invenção de uma nova cultura. Era forjada a causa comum pela construção nacional, entretanto, os projetos estavam marcados pela divergência. Uma verdadeira batalha desdobrava-se no meio cultural, de um lado por "marxistas oficiais", de outro os "marxistas críticos".

Franco Fortini e, mais tarde, seu interlocutor Pier Paolo Pasolini, entram em cena como intelectuais atuantes na Itália, compreendiam, cada um a sua maneira, que era preciso pautar os recursos de estilo por uma poética experimental nova, que resgatasse a livre invenção individual, recusavam os preceitos de partido; já os defensores do historicismo, vinculado a Gramsci, Lukács e Labriola, fixavam conceitos no plano da literatura em paralelo à sua reflexão política, solidários às preocupações partidárias e, com uma plataforma expressamente antifascista, defenderam o humanismo de novas feições e o realismo na arte.

Nos anos 60, na Itália, encerra-se o caso italiano: "é o fim da hegemonia da cultura de esquerda e do marxismo italiano, que caracterizou marcadamente toda a reflexão italiana desde o pósguerra, posterior a outro movimento hegemônico, o idealismo de matriz crociana" (AMOROSO, 1997, p. 31). Também nesse período 
ocorre a expressão máxima da cultura norte-americana no país. A Itália vive seus momentos de intensa “americanização cultural”. A correspondente organização política e cultural leva o discurso literário à nova instância, como apresenta a pesquisadora Maria Betânia Amoroso:

Nos anos 60, o discurso que unia o ético ao literário, ponto básico da crítica militante, se radicaliza na defesa do especifico literário, propondo como exemplo, na figura de Renato Barilli, do neovanguardista Grupo 63 (o 63 se refere à data de formação do grupo) - a separação definitiva entre o literato-homem público e o literatoliterato. (1997, p. 33).

Os estudos literários são deslocados para o texto, para o signo ou para a substância da psicanálise no trabalho de crítica simbólica. Assim, permaneceu difícil a construção da crítica militante a partir dos anos 70. A “modernização" da Itália foi o retrato do processo de transformação dos padrões de comportamento. Essa circunstância histórica de imposição de um modelo cultural único desencantou os artistas e implicou a recusa ao dogmatismo.

O abismo orgânico exigiu novo aprendizado sensorial de Murilo Mendes e observa-se, nas obras posteriores aos anos 60, acentuada tendência libertária, como em Murilogramas, juntamente com uma linguagem que evoca a universalidade e quer acentuar o processo de afirmação da identidade nacional a partir da vivência relacional com a cultura europeia.

$\mathrm{O}$ poeta assume o ofício da poesia que fala desde a subterraneidade, conforme o termo utilizado por Cecília Garcez, e que parece ser compartilhado também por Maria Betânia Amoroso: "nestas marcas de leitura é evidente o interesse de Murilo em 
investigar as suas origens, de conhecer o elemento humano, forjador do presente, mas também de encontrar elementos, para adentrar-se nos mistérios de todos os homens, de todos os tempos e lugares" (AMOROSO, 1997, p. 98). As variações nas condições geográficas e culturais trazem à sensibilidade novos ângulos de correspondências ocultas. Seu entendimento pede abstração, sua ocorrência superpõe biografia, acontecimentos, instante: "a mineiridade" encontra-se com a geografia siciliana.

\section{A Contemplação da Sicília}

A linguagem poética vigorosa de A Contemplação de Ouro Preto, com sua visível matriz emotiva e seu efeito plástico-visual, arrebanha organicamente a obra Siciliana (1954-1955), com alusões à memória-coletiva daqueles que povoaram este lugar, ao mesmo tempo árido e envolvido pelas águas do mediterrâneo. A resolução reflexiva que contrapõe a Minas de Ouro Preto, distante do mar, mas exuberante pelos sentimentos de comoção que a aguda beleza religiosa revela, é contraposta à grandiosidade do mistério que o oceano e o ambiente seco evocam, mas ambos os lugares, ligados pela interdependência dos aspectos históricos, funcionam como sinônimo de construção da identidade/alteridade de Murilo Mendes.

São versos motivados por paradigmas que fazem da rememoração do passado o preâmbulo para fazer sobressair a interrelação entre sincronia-diacronia das coisas, da paisagem, dos tempos.

Em Siciliana, Murilo Mendes acentua o elemento físico, muito embora, para fazê-lo, o autor utilize o experimentalismo estilístico com a tendência classicizante que o caracterizava nesse momento. $\mathrm{O}$

Revista Texto Poético | ISSN: 1808-5385 | Vol. 18 (10 sem-2015) - p. 121 
autor une a secura da paisagem à redução da sintaxe, mas não abandona a vigência da dimensão cromática. Os elementos sintetizam a montagem imagística com a preocupação essencial de falar da significância desse contexto cultural que é vivenciado em sua peculiaridade pelo Murilo Mendes mais experiente.

Começava um redimensionamento da escritura muriliana. Após Tempo espanhol (1959), o poeta encerraria esse experimentalismo atento ao rigor da forma e passaria a referir-se à articulação dos procedimentos poético-biográficos, quando irá fundir poesia e prosa, compondo as experiências fruto do contato pessoal que foram a substância de seu projeto ético-estético: configurar presenças, falar do contato com os Outros que plasmaram a vida e a obra do autor.

Escrita entre 1954 e 1955, Siciliana foi seu primeiro livro publicado na Itália. Editado em 1959, o livro, com edição ítaloportuguesa, teve prefácio de Giuseppe Ungaretti e tradução de A. A. Chiochio. Composto por treze poemas, em cujas variantes ressaltam-se os elementos da atmosfera siciliana, estabelecida desde o primeiro poema "Atmosfera siciliana", para finalizar com "O Eco de Siracusa”. As imagens frequentes nos versos justificam a conjunção de multiformes civilizações que aportaram nessa ilha mediterrânea.

O destaque inicia pela toponímia: Sicília tem o nome dos Sículos e Sicanios, antigos povos que habitaram a região, mais tarde ocupada por fenícios, gregos, cartagineses, romanos, germanos, árabes, franceses, espanhóis. $\mathrm{O}$ autor anuncia essa plural expressão pelo percurso que estabelece nos poemas. Leia-se: 
Correspondendo a fragmentos de astros,

A corpos transviados de gigantes,

A formas elaboradas no futuro,

Severas tombando

Sobre o mar em linha azul, as ruinas

Severas tombando

Compõem, dóricas, o céu largo

Severas se erguendo,

Procuram-se, organizam-se,

Em forma teatral suscitam o deus

Verticalmente, horizontalmente.

Nossa medida de humanos

- Medida desmesurada -

Em Selinunte se exprime:

Para a catástrofe, em busca

Da sobrevivência, nascemos.

(MENDES, 1997, p. 566)

Assimetria revelada pela ambiguidade das formas: "severas tombando / severas se erguendo", nas quais se estabelece um jogo estético que percorre esse mundo enfraquecido. Entorpecedoras ruínas, de significados conotativos, estão rodeadas pelo mar e sob o sentido do largo céu, nesse contexto em que nomes e coisas se comunicam pelo signo da catástrofe. Aqui as ruínas representam a metáfora da descontinuidade, despertam a mente, estimulam o corpo a descobrir algo nos escombros. Remetem ao passado, às origens, in illo tempore a fim de buscar a época ideal, inacessível.

Murilo Mendes se converte em tradutor, o tecido linguístico do poema busca impertinente por respostas; abstração inspirada pela imagem da queda, e queda torna-se descida, oficializa o mistério da busca de constância na fluidez temporal, isto é, a angústia humana diante da temporalidade. A iconografia simbólica grega é observada 
pela organização teatral do espaço, o passado mítico se faz presente no verso "corpos transviados de gigantes", já o substrato da cultura romana é valorizado no poema quando o sujeito lírico adensa tenacidade, persistência, arquétipos políticos por excelência. Quando menciona as "colunas dóricas", há uma fusão mítica que exalta essa civilização guerreira e jurídica, mas ao mesmo tempo agrícola e doméstica, como afirma Gilbert Durand (2001, p. 266).

Esse realismo sensorial prima pela quietude desse voltar para trás, obsessão pelo tempo e pela finitude, a qual Gilbert Durand justifica como uma epifania do ciclo (2001, p. 295) e pela qual se capta uma visão rítmica do mundo, ritmo realizado pela sucessão dos contrários, alternâncias antitéticas: vida/morte, forma/latência, ferida/consolação. Essa propensão imagística é acentuada pela representação do espaço, porque a ilha tem forte conotação feminina de retorno ao ventre: o centro espiritual primordial.

Portanto, confirma-se a estética moderna de pensar as raízes com um forte apelo utópico. Esse quadro histórico do mundo moderno está igualmente disposto para o olhar de Murilo Mendes no poema:

DESPEDIDA DE CEFALU

Em pedra e horizonte ficas.

É triste deixar tua força

No duro penhasco plantada,

Que o sol vertical aumenta.

Respiras nesta grandeza

Que nos vem da água, da luz

E da terra percutida,

Do peixe. Contigo vamos

Na roda cósmica, e o vento.

Revista Texto Poético | ISSN: 1808-5385 | Vol. 18 (10 sem-2015) - p. 124 
Não te adornas para o culto:

Cefalu solene e pobre

Em duro penhasco plantada,

Teu rito é de antiga origem:

Vem da alma rude e sem véu.

Assim te amam os pescadores,

Com esta força e gravidade

Extraídas da tua rocha

Que o sol vertical aumenta.

(MENDES, 1997, p. 567)

Neste poema há uma prevalência de expressões que aglutinam a substância primordial do mundo: sol, água, luz, peixe, vento. Notem-se as imagens das "águas" como princípio e fim dos acontecimentos cósmicos. O "mar", arquétipo de descida e retorno às fontes de felicidade. Segundo Gilbert Durand, o culto da Grande Mãe e a sua referência filosófica oscila entre o simbolismo aquático e o simbolismo telúrico. Aqui o tema é o "dia", intenso, nessa constelação de imagens que têm no Sol, como explicam Chevalier \& Gheerbrant, "o símbolo da vida, da luz, da autoridade, sexo masculino e de tudo o que brilha" (1997, p. 839).

O "vento" anuncia a instabilidade, a inconstância: "peixe" é símbolo de vida, fecundidade, para os cristãos, a imagem do Cristo, símbolo das águas, o peixe está associado a várias qualidades, inclusive, ao nascimento ou à restauração cíclica (1997, p. 703). Essa espiral de figuras prolonga-se ainda mais ao referir-se a pedra, rocha, penhasco, horizonte, véu.

A pedra é o símbolo da ação humana que substitui a energia criadora, força de outrora plantada no duro penhasco. O lugar, agora pobre e rude, está sem "véu", sem ilusão, nada se oculta. Essa limitação é intensificada pela luz do sol vertical, isto é, visível. Revelam-se os ultrajes do tempo que a nada pode reparar. Mas

Revista Texto Poético | ISSN: 1808-5385 | Vol. 18 (10 sem-2015) - p. 125 
Longe de estar às ordens do tempo a memória permite um redobramento dos instantes e um desdobramento do presente; ela dá uma espessura inusitada ao monótono e fatal escoamento do devir, e assegura nas flutuações do destino a sobrevivência e a perenidade de uma substância. (DURAND, 2001, p. 402).

A alma rude e sem véu se levanta contra esse nada do tempo, reage contra esse poder dissolvente da lucidez, porque "é essa saudade enraizada no mais profundo e no mais longínquo do nosso ser que motiva todas as nossas representações e aproveita todas as férias da temporalidade para fazer crescer em nós, com a ajuda das imagens das pequenas experiências mortas, a própria figura da nossa esperança essencial" (DURAND, 2001, p. 403).

O poema diz sobre a condição humana. Seus símbolos se encontram vinculados ao ser, ao Mundo e à Vida, expressam esse desejo humano de se resguardar do total desaparecimento. Essa consciência da aventura espiritual que pretende negar o devir fatal também é inventariada no poema:

\section{O ECO DE SIRACUSA}

Nas tuas cavernas oblongas

Há um deus que se levanta,

Reconstituído no eco:

Toquemos o mundo com a voz.

Jardins que explodem, latomias guardam

O sopro físico da passagem

De antiga morte em Siracusa:

Violenta marcha a história nas tuas lajes,

Súbito estanca. 
Eis que o drama

Se desarticula

Porque o deus ministra

Oráculos espessos:

Mas o eco éforte,

Só ele se mantém

Mais vivo do que o

Augúrio original.

Foi tua força extinta,

Pétrea Siracusa,

Mas o gongo aéreo,

Mas o longo eco

Te reconstitui.

Áspera voz, duplo eco

Habitado pelo deus

Que subsiste ainda

No homem inumano

Eco.

(MENDES, 1997, p. 573)

A superfície linguística dos símbolos liga-se à natureza emotiva que o espaço das "cavernas oblongas" assegura. Este espaço é um convite à intimidade, à viagem longínqua que deve iluminar percepções sensoriais com urgência de tradução. A partir dessa topografia, eleva-se a transcendência, precisamente, pela alternância entre a descida psíquica, capaz de reconstituir o eco, dual, restaurador ou subsistência silente no homem inumano que não o escuta.

Esse oráculo que decifra o "eu" tem direção qualitativa ou instala a figuração do eco hipnótico, inacessível, obsedante, destruidor desses indícios de queda que usurpam a plenitude do ser. O homem necessita procurar bem, ser intérprete de si mesmo ou, do contrário, perder sua força, aguardar sua própria destruição. 
O poema alude à representação das faces do tempo e apresenta o sintoma, eufemizado, do aniquilamento de uma época. A linguagem simbólica recobre uma significação que pensa a situação do homem no mundo.

A ilha siciliana, centro espiritual primevo, segundo Chevalier \& Gheerbrant, é o lugar de eleição, de silêncio e de paz, em meio à ignorância e à agitação do mundo profano, evoca "o refúgio, onde a consciência e a verdade se uniriam para escapar aos assédios do inconsciente: contra os embates das ondas o homem procura o socorro do rochedo" (1997, p. 502).

\section{Elementos da imaginação material na poesia de Murilo Mendes}

A poética moderna foi capaz de reconduzir seu objeto de análise também para o campo dos símbolos, leitura empenhada em descobrir uma espécie de continuidade expressiva no interior dos textos de cada escritor. Verifica-se que uma pesquisa sobre o vínculo entre o mito e a literatura sublinha um convite à atitude interdisciplinar, através da qual haverá a ampliação do entendimento do fenômeno simbólico. Ana Maria Lisboa de Mello explica:

Diante de um leque de posições, privilegiam-se as hermenêuticas que resgatam a importância do processo de simbolização nas relações do homem com o cosmos. $\mathrm{Na}$ seleção do referencial teórico que fundamenta a crítica do imaginário, Gilbert Durand destaca-se como um dos teóricos que afirma a primazia do sentido simbólico (ou figurado), considerando que o figurado não é um epifenômeno ou um ornamento que recobre uma significação positiva, mas o elemento cuja hermenêutica 
revela a face obscura, noturna e profunda da linguagem, desveladora da intimidade subjetiva. (2002, p. 12).

Todos esses fatores encontram-se mergulhados nas circunstâncias estruturais que a lírica moderna, a partir de seu precursor Baudelaire, tornou elemento comum, tensionando os estratos pré-racionais enquanto critério dominante, pelo comportamento estilístico inquieto, para um polo de produção que se desprende da realidade temporal, espacial e objetiva. Notam-se novas inclinações capazes de suscitar o fascínio pelo pensamento simbólico na contramão dos conceitos positivistas característicos do séc. XIX, porque

Uma feliz conjunção temporal fez a Europa Ocidental redescobrir o valor cognitivo do símbolo no momento em que ela não é a única a 'fazer história', e a cultura europeia, a menos que se enclausure em um provincialismo esterilizante, é obrigada a contar com outras vias de conhecimento, com outras escalas de valores que não apenas as suas. (ELIADE, 1991, p. 7).

As imagens, os sonhos, os devaneios são forças que projetam o homem a dimensões infinitamente mais ricas; admitir tais referências no plano imediato significava aniquilar as interpretações racionais para encontrar algo completamente diferente que seguramente haveria de restituir a "nostalgia do paraíso". Foi preciso desfazer-se das concepções reinantes de ordem e realidade e filiar-se a campos de representação em constante mudança, para compreender que o aspecto crucial gerado pelo desencanto com o propósito maior da eficiência materialista afetara o desenvolvimento da arte.

E, apesar da evidência de que nessa transformação não havia consenso, entre todos os artistas a antipatia expressa contra a arte anterior

Revista Texto Poético | ISSN: 1808-5385 | Vol. 18 (10 sem-2015) - p. 129 
era altamente significativa, mas houve escritores que redimensionaram aqueles elementos e conseguiram abrir caminhos próprios para a conquista de novas expressões.

O espírito de renovação da escritura artística, concebido como possibilidade crítica, trouxe à poesia uma base sensorial reveladora do mundo das sensibilidades integradas, permitiu a aceitação do poema "como objeto feito da linguagem, dos ritmos, das crenças e das obsessões deste ou daquele poeta, desta ou daquela sociedade" (PAZ, 1984, p. 11). $\mathrm{E}$, diante do desafio apresentado pelas diferenças entra as línguas e as culturas ocidentais, parece que a poesia moderna é essencialmente esboçada pela unidade em sua tessitura linguística em seus fundamentos, pulsões, critérios e que são suscetíveis de investigação.

Percorrer a cartografia do imaginário de um autor é uma tarefa instigante que tem lançado, progressivamente, a pesquisa a resultados substanciais, porque a topografia das imagens próprias de uma obra se afirma pela morfologia inscrita na paisagem. Os símbolos deslocam sentidos numa verdadeira simbiose entre o devaneio e a realidade, entre o visível e o invisível. Há em tal linguagem a alusão à geografia, porque as relações estabelecidas precisam ser alimentadas pelos atributos espaciais, possibilitando apreensões, justificando intencionalidades.

No plano da criação literária, a obra de Murilo Mendes está marcada pela afirmação de múltiplas e sucessivas metamorfoses. A forma, o conteúdo e a expressão se organizam em estado incessante de tensão, característica que, aliada à imaginação, torna-se a força operante da inovação. Nesse quadro, no qual se generaliza o uso do termo polidimensionalidade $^{15}$ (FRIAS, 2002, p. 113), se estabelece a irrupção

\footnotetext{
${ }^{15}$ Joana Matos Frias, pesquisadora da obra de Murilo Mendes, formulou o conceito para fazer alusão às múltiplas e sucessivas metamorfoses, como afirmação evidente da raiz barroca do autor.
}

Revista Texto Poético | ISSN: 1808-5385 | Vol. 18 (1o sem-2015) - p. 130 
da diversidade imagética, ocasionando flutuações, desdobramentos poliédricos, irregularidades.

Em outras palavras, evidencia-se o direito à surpresa, a rejeição de certezas, a impossibilidade da síntese definitiva, curiosa dialética que, no plano da obra, engendra as perspectivas mais vivas do processo histórico habitual para o autor.

Murilo Mendes constrói através desses vários focos de energia a ideia do saber como atividade em permanente movimento, concilia razão e experiência, amplia noções, reorganiza suas bases, prodigioso trabalho de alimentar a imaginação.

Diante da organicidade assimétrica que oferece à forma inúmeras possibilidades dinâmicas, as imagens do sistema simbólico proliferam nesse "Atlas" que a partir de agora será valorizado pelo regime noturno e diurno, segundo a Teoria do Imaginário de Gilbert Durand. Posteriormente, agrupam-se as instruções de Gaston Bachelard para os estudos do devaneio, pelas forças materiais relativas aos quatro elementos: terra, ar, água e fogo.

Na perspectiva inerente às imagens da água, desvendam-se traços díspares. As vozes da água, mudas ou ruidosas, ensinam sobre as circunstâncias nas quais a terra siciliana transformou choques em graça; a descoberta do Outro aparece na áspera e delicada ilha, verdadeira encruzilhada no mar mediterrâneo, pela qual dezenas de grupos étnicos passaram, combinando confrontos e doces heranças, mas as imagens de suavidade agora coexistem e se deixam superar pela representação dos valores terrestres: 


\section{O CLAUSTRO DE MONREALE}

Abstrato e longe achei-me

No espaço de colunas geminadas.

A água oriental

Segreda a passagem súbita

Do nada ao ser,

E, fluida, se transforma

Quem nos dera, subindo as mãos,

Volver ao modelo antigo,

A queixa da alma domar.

Bebemos da solidão,

Solidão de luz e pedra

Elaborada pelo homem.

Talvez que estas flores

Sejam até demais.

Confronto-me ao que foi antes de mim:

Em 1901 eu tinha

Seis milhões de anos.

Os que dormem sob as lápides,

Antecipando o futuro,

Viram o deus permanecer

Desde o princípio do tempo

Nas colunas geminadas.

(MENDES, 1997, p. 569)

A dicção poética resultante do contato com a beleza desafiadora do espaço de Monreale experimenta a confluência da "água oriental", primordial elemento de caráter feminino, dinamizada como embrião que dá a vida, isto é, há uma referência aos povos que chegaram para colonizar a ilha, trazendo a passagem súbita do nada ao ser, fluida, se transforma, une-se a adequação da forma à imagem valorizada da pureza da água com a configuração da subjetividade terrestre. É preciso dizer sobre o espaço vital contemplado como microcosmos, devido à alusão às colunas geminadas, que revelam

Revista Texto Poético | ISSN: 1808-5385 | Vol. 18 (10 sem-2015) - p. 132 
forças de levantamento, juntamente às impressões do ritmo das forças humanas limítrofes às forças do universo "ao que foi antes de mim", ou seja, ao macrocosmo. Chamam a atenção a vontade, a destreza, os valores extrovertidos elaborados pelo homem e delineados sobre um fundo de universo, espetáculo grandioso em sua trajetória "de seis milhões de anos": "parece, então, que é por sua 'imensidão' que os dois espaços - o espaço da intimidade e o espaço do mundo - tornam-se consoantes. Quando a grande solidão do homem se aprofunda, as duas imensidões se tocam, se confundem" (BACHELARD, 1993, p. 207).

O poder aéreo tem a dinâmica triunfante da ascensão, dos desejos de voo, do desejo de crescer, quer dizer, é a substância primordial da vontade de liberdade, a sua outra face apresenta-se pela imagem da queda. Em outras palavras, pode-se dizer que a dimensão simbólica do ar volta-se às questões referentes à fuga diante do tempo ou à vitória sobre o destino; isto é, move-se pela expressão filosófica em sua luta contra as trevas, a queda, a animalidade.

Prestar atenção aos sinais do tempo tem implicação dramática, atualizar essas reflexões significa tecer redes de relações entre o emocional, o sensível e o estético; é pelo regime diurno que essas distensões perceptivas opressivas são inventariadas e afrontadas através da palavra em movimento que evoca abstrações: "há imagens literárias que nos engajam em reflexões indefinidas, silenciosas. Percebemos então que na própria imagem se incorpora um silêncio em profundidade" (BACHELARD, 2001, p. 259).

Portanto, em verso ou prosa, a imensa paisagem estimula a pronúncia da profundidade interior do homem. Ocorre um estado de devaneio que tem poder iluminador: "existe um devaneio do olhar

Revista Texto Poético | ISSN: 1808-5385 | Vol. 18 (10 sem-2015) - p. 133 
vivo, devaneio que se anima num orgulho de ver, de ver claro, de ver bem, de ver longe, e esse orgulho de visão é talvez mais acessível ao poeta que ao pintor: o pintor deve pintar essa visão mais elevada, o poeta se limita a proclamá-la" (BACHELARD, 1988, p. 176). Mas o que dizer do poeta que colore com as palavras como Murilo Mendes?

Com ele a denominação plástica ganha ocorrência fundamental: "como marcada pela atenção à visualidade, ao físico, ao concreto, ao espaço, e assim por diante, são modos assemelhados de aproximação a uma questão diversificada em sua realização" (GUIMARÃES, 1993, p. 63), possibilitando também pensar sobre as virtualidades do real instruídas pelas figuras sensíveis da alteridade:

\section{O TEMPLO DE SEGESTA}

Porque severo e nu, desdenhas o supérfluo,

Porque o vento e os pássaros intocados te escolhem,

Sustentas a solidão, manténs o espaço

Que o homem bárbaro constrange.

Em torno de tuas colunas

O azul do céu livre gravita.

Que música nos vem do número e da paz,

Que música nos vem do espaço organizado.

Propício ao ritmo é o deus do número,

E pela sequência do ritmo

A unidade do tempo se reconstrói.

A Segesta com amor e lucidez eu vim

Colher o que a morte não selou,

Sondando o oráculo que és tu mesmo,

Tuas linhas de força e calma pedra. 


\section{O espirito em diagonal te aceita}

Para romper a angústia das origens:

Na luz afiada de Segesta

Forma e solidão se ajustam.

(MENDES, 1997, p. 566).

É possível conceber o destino do homem cifrado numa imagem porque no poema ocorre o movimento cíclico de ascensão e queda, descobre-se o estágio que foi elemento expressivo da história da Sicília e que, agora, o ciclo da destruição tornou emblemático, porém ampliado. O sujeito poético mostra-se reflexivo, empenhado em reler a "angústia das origens", ao mesmo tempo em que faz aparecer a representação do tempo em seu caráter dialógico vinculado ao jogo de intersignificações dirigido às expectativas para o futuro e para $o$ passado. A partir do espaço da ilha siciliana, misto de aridez e lugar de intimidade, imensidão do mar e fluido aéreo, assim como força imaginativa da energia ígnea suscitada pelo Sol, projeta-se num diagrama poético, prova ou suposição capaz de afastar do corrosivo esquecimento a dimensão do agir e a dimensão do padecer desses Outros que partilharam o lugar. A cálida intimidade terrestre, silente oráculo guardado na pedra, transmite evidências das gerações anteriores, faz o passado escapar às cronologias, mas também adiciona a reinterpretação desses conteúdos carregados de sentido. As colunas são alusivas à civilização greco-latina do sul da Itália, são o "rastro" deixado pela forma, já a música do número e da paz, do espaço organizado pelo ritmo e pelo deus número, é a tradição transmitida e recebida, ambas em profunda afinidade: "se a tradicionalidade constitui a dimensão passada do espaço da experiência, é no presente que esse espaço é reunido e pode ampliarse ou encolher-se" (RICOUER, 1997, p. 391). 
Murilo Mendes imprime seu caráter, vigilante e fascinado, traduz o tempo físico e transmite senhas para a decifração desse maravilhoso espetáculo da vida. No espaço monumental da Sicília, onde a glória de antigas culturas inscreveu seu nome, o orgulho fértil e o tom áspero encontram-se com a pesada rocha e com o ígneo enxofre:

\section{CANÇÃO DE TÉRMINI IMERESE}

A Términi Imerese eu vim,

De Términi Imerese eu vou.

Pesquiso a forma no caos,

Pesquiso o núcleo do som.

Ó pedra siciliana,

Enxofre, mar de cobalto;

Sondei a força concreta

Dos elementos, do deus.

Mas quem, o sol desvendando,

À terra me comunica?

Sem o filtro da morte quem

Me faz absorver o azul?

A Términi Imerese eu vim,

De Términi Imerese eu vou.

Transformei-me à minha imagem,

E o mesmo oráculo sou.

(MENDES, 1997, p. 568).

Diante da matéria surge a revelação da vontade de agir, espécie de onirismo ativo unindo imaginação e vontade num mundo onde a beleza e a morte são limítrofes; a força humana em lugares, como a ilha siciliana, tem emergências, porque as substâncias do sol, do mar de cobalto, do azul e da pedra dirigem energias, reclamam a 
transposição da imensidão. Para durar, é preciso agir, e imaginar que os elementos segredam lucidez ou derrotas.

No mesmo instante em que aparecem imagens de beleza, a função do elemento enxofre no poema traz a propriedade da ação transmutadora, princípio gerador masculino correspondente ao fogo, neste caso, aquele que em sua força esterilizante espalhará na terra o aspecto infernal: "para os alquimistas, o enxofre estava para o corpo como o sol está para o universo, o ouro, a luz, a cor amarela, interpretadas no sentido infernal de seu símbolo, denotam o egoísmo orgulhoso que só busca a sabedoria em si mesmo, que se torna a sua própria divindade, seu princípio e seu fim" (CHEVALIER \& GHEERBRANT, 1997, p. 374). E, ainda, por sua própria força que a maneira de viver nessa paisagem, suscitada pelo abismo rochoso, pela presença ameaçadora da força invencível do enxofre ígneo, que o ventre da terra torna-se opressivo; o sujeito lírico filtra os limites da matéria e absorve a solidez íntima que o lugar lhe confere, transforma sua imagem: "na paisagem dinamizada pela pedra dura, pela rocha de basalto ou de granito, um rugido negro cava o abismo. O rochedo grita" (BACHELARD, 2001, p. 160); e, entre o rochedo e as águas, imagens de profundidade induzem à procura do oráculo, espelho, sutileza interior, profundidade legendária, verdadeiro regresso à mãe. Há uma busca por todos os enigmas humanos, devaneio de natureza dinâmica noturna, ida e volta para pesquisar a "forma do caos" e o "núcleo do som": "assim uma espécie de onirismo panorâmico responde à contemplação da paisagem, cuja profundidade e extensão parecem chamar os sonhos do ilimitado" (2001, p. 301), passagem que amplia as forças íntimas. 


\section{Considerações finais}

O vocabulário no projeto estético de Murilo Mendes instaura sentidos de intenso conteúdo existencial, sugere traços, reencontro com a inefável beleza da vida: "o símbolo é, como alegoria, recondução do sensível, do figurado ao significado, mas é também, pela própria natureza do significado inacessível, epifania, isto é, aparição, através do e no significante, do indizível" (DURAND, 1993, p. 11).

Murilo em inúmeras viagens alimentou-se de palavras e de silêncios que os encontros da identidade com a alteridade permitiram. A partir dessas circunstâncias, organizou a narrativa na estrutura não linear, lições importantes de uma materialidade artística que tem alcance contextual: "homem de tantos relacionamentos e de experiência intelectual ilimitada, Murilo Mendes não se recusa a desdenhar o séc. XX (incapaz, a seu ver, de construir grandes praças) e a lamentar o processo de banalização da cultura a que a automação e o espírito burguês levaram a civilização contemporânea" (LUCAS, 2001, p. 6).

Compelido ao trabalho literário, o autor admite o entrecruzamento entre os vários planos, realidade e sonho, vivido e imaginário, passado e presente. $\mathrm{O}$ autor baseia a sua poesia na sensação e na verdadeira força operante dos desdobramentos, e da pluralidade da construção da consciência de si. Murilo Mendes circunscrito na modernidade, e no diálogo com a alteridade, convive com o inexorável racionalismo, mas valoriza os sentidos e as imagens, funde seu projeto poético no prazer sensorial, intelectual e estético. A liberdade enfim alcança a universalidade. 
Ele confirma a sua recusa de falar da realidade nos limites de uma interpretação exclusiva. Para o autor, a anulação do tempo objetivo torna possível a coexistência de vários sistemas literários, por isso defendeu que os mesmos estão marcados pela pluralidade e pela descontinuidade essenciais.

O compromisso do autor com esta atitude encontra na escrita transtextual a descrição da rede de alteridades que o ajudou a elaborar sua obra, porque refundiu os dados do passado reconstruindo-os no presente com outra função, admitiu a ampla influência de pintores, músicos, poetas, cineastas como patrimônio interpretativo, fontes de sentidos que haveriam de estimular a forma, o conteúdo e a expressão de Murilo Mendes, atualizando-o permanentemente. Para nós, leitores de Murilo, puro deleite!

\section{Referências}

AMOROSO, Maria Betânia. A paixão pelo real: Pasolini e a crítica literária. São Paulo: Edusp, 1997. (Ensaios da Cultura: 11).

ARAÚJO, Laís Corrêa. Murilo Mendes. Petrópolis, RJ: Vozes, 1972.

BACHELARD, Gaston. A água e os sonhos: ensaio sobre a imaginação da matéria. Trad. Antonio de Pádua Danesi. São Paulo: Martins Fontes, 1997.

. A dialética da duração. Trad. Marcelo Coelho. São Paulo: Ática, 1988a.

. A poética do devaneio. Trad. Antonio de Pádua Danesi. São Paulo: Martins Fontes, 1988b.

. A poética do espaço. Trad. Antonio de Pádua Danesi; revisão de tradução Rosemary Costhek Abílio. São Paulo: Martins Fontes, 1993.

. A psicanálise do fogo. 2. ed. Trad. Paulo Neves. São Paulo: Martins Fontes, 1999. 
. A terra e os devaneios do repouso: ensaio sobre as imagens da intimidade. 2. ed. Trad. Paulo Neves. São Paulo: Martins Fontes, 2003.

. A terra e os devaneios da vontade: ensaio sobre a imaginação da forças. 2. ed. Trad. Maria Ermantina Galvão. São Paulo: Martins Fontes, 2001.

. O ar e os sonhos: ensaio sobre a imaginação do movimento. 2. ed. Trad. Antonio de Pádua Danesi. São Paulo: Martins Fontes, 2001.

. O novo espírito científico. Seleção de textos de José Américo Motta Pessanha; traduções de Joaquim José Moura Ramos [et. al.]. São Paulo: Abril Cultural, 1978.

BHABHA, Homi K. O local da cultura. $1^{\text {a }}$ reimpressão. Trad. Myriam Ávila, Eliana L.L. Reis, Gláucia R. Gonçalves. Belo Horizonte: Editora da UFMG, 2001.

CHEVALIER, Jean e GHEERBRANT, Alain (orgs.). Dicionário de símbolos. 11. ed. Coord. Carlos Sussekind; trad. Vera da Costa e Silva. Rio de Janeiro: José Olympio, 1997.

DURAND, Gilbert. Campos do Imaginário. Lisboa: Instituto Piaget, 1998.

.O imaginário: ensaio acerca das ciências e da filosofia da imagem.

2. ed. Trad. René Eve Levié. Rio de Janeiro: Difel, 2001b.

- As estruturas antropológicas do imaginário: introdução à arquetipologia geral. Trad. Hélder Godinho. São Paulo: Martins Fontes, 2001a.

. A Imaginação simbólica. Trad. Carlos Aboim de Brito. Lisboa: Edições 70, 1995.

. A fé do sapateiro. Trad. Sérgio Bath. Brasília: Editora Universidade de Brasília, 1995. 
ELIADE, Mircea. Imagens e símbolos: ensaios sobre o simbolismo mágicoreligioso. Prefácio de Georges Dumézil; trad. Sonia Cristina Tamer. São Paulo: Martins Fontes, 1991.

. O sagrado e o profano: a essência das religiões. Trad. Rogério Fernandes. São Paulo: Martins Fontes, 1992.

FRIAS, Joana Matos. O erro de Hamlet: poesia e dialética em Murilo Mendes. Rio de Janeiro: 7 letras; Juiz de Fora; Centro de Estudos Murilo Mendes-UFJF, 2002.

GARCEZ, Cecília de Macedo. Destecendo os fios da memória: a escrita memorialística de Murilo Mendes entre o tempo pretérito e o tempo presente. Dissertação de Mestrado. UFJF, 2000.

GUIMARÃES, Julio Castañón. Em torno de Tempo Espanhol. MELLO, Ana Maria Lisboa de (org.). Cecília Meireles \& Murilo Mendes. Porto Alegre: Uniprom, 2002.

. Territórios/conjunções: poesia e prosa críticas de Murilo Mendes. Rio de Janeiro: Imago Ed., 1993.

LUCAS, Fábio. Na época do transistor. Revista Murilomundo: um passeio pela obra do poeta Murilo Mendes no ano do centenário de seu nascimento. Suplemento literário especial, Belo Horizonte, jul. 2001.

MELLO, Ana Maria Lisboa de. Vanguardas e pós-vanguardas na poesia brasileira: do concretismo à poesia marginal. In: Ciências e Letras, n. 71986. (Revista da Faculdade Porto-Alegrense de Educação, Ciências e Letras).

. Poesia e imaginário. Porto Alegre: EDIPUCRS, 2002.

MENDES, Murilo. Poesia Completa e Prosa. Rio de Janeiro: Nova Aguilar, 1997.4v. (1.784 p.). - (Biblioteca Luso-brasileira. Série brasileira).

. Transistor: antologia de prosa. Seleção do Autor e de Saudade Cortesão Mendes. Rio de Janeiro: Nova Fronteira, 1980. 
MERQUIOR, José Guilherme. O fantasma romântico e outros ensaios. Rio de Janeiro: Vozes, 1980.

MORICONI, Ítalo. Murilo Mendes e o cânone. RIBEIRO, Gilvan Procópio e PINHO, José Alberto (orgs.) Murilo Mendes: o visionário. Juiz de Fora: Editora da UFJF, 1997. (Ideias).

NORA, Pierre. Entre memória e história. A problemática dos lugares. Trad. Yara Aun Khoury. In: Proj. História, São Paulo, n. 10, dez 1993.

PAZ, Octavio. Os filhos do barro: do romantismo à vanguarda. Trad. Olga Savary. Rio de Janeiro: Nova Fronteira, 1984.

PEREIRA, Maria Luiza Scher. Tempos de Murilo - II Visita ao acervo do poeta: as obras e as margens. Revista de estudos literários Ipotesi. Juiz de Fora, v. 6, n.1, pág. 11-18, jan./jun. 2002.

PICCHIO, Luciana Stegagno. A Itália de Murilo. Revista Poesia Sempre. Rio de Janeiro. n. 14, agosto 2001.

PIZARRO, Ana (org.). América Latina: palavra, literatura e cultura. Vol. 3. São Paulo: Memorial, 1993-1995.

RICOUER, Paul. Tempo e narrativa. Tomo III. Trad. Constança Marcondes César. Campinas, SP: Papirus, 1997.

. Interpretação e ideologias. Organização, tradução e apresentação de Hilton Japiassu. Rio de Janeiro: Francisco Alves, 1988. 